\title{
Directions of Valley Axes in Relationship to Geological Structure-Element Orientation in the Stríbrné Hory Area in the Bohemian-Moravian Uplands (Czech Republic)
}

\author{
Jan Juráček ${ }^{1,2,3}$ and Rostislav Melichar ${ }^{1}$ \\ 1. Department of Geological Sciences, Faculty of Science, Masaryk University, Kotlářská 2, CZ-611 37, Brno \\ 2. Interdisciplinary Research Centre, Faculty of Arts, University of Hradec Králové, Rokitanského 62, CZ-500 03 Hradec Králové \\ 3. Department of Science, Museum of East Bohemia, Eliščino nábřeži 465, CZ-500 01 Hradec Králové
}

\begin{abstract}
The purpose of this paper is to evaluate control of orientation of foliations and joints on the direction of valley axes in the Stríbrné Hory area in the Bohemian-Moravian Highlands in central part of the Czech Republic. This area is predominantly built by metamorphic rocks. It is situated near the Přibyslav deep-seated fault. The data concerning of foliations, joints and valley axes were statistically analyzed and then visually compared according to their distribution using direction roses. Directions of valley axes have generally orientation of NNE-SSW, SE, E-W, NW and WNW and coincide with the system of foliations and ordinarily steep joints.
\end{abstract}

Key words: Bohemian-Moravian Uplands, tectonics, foliations, joints, valleys.

\section{Introduction}

This paper represents an experiment of evaluation of the directions of valleys in a relation to geological structures. The distributions of valley axes lengths were compared to the orientations of geological structures. The relationship between valley axes and geological structures has already solved by other author's methods of vector analysis of valley axes [2]. The structures and the lithology control a degree of the fragmentation of the landscape, final types and density of valley net. They shape distribution of slopes, width of valleys, power of streams and accessibility of materials for supplying to flow [1].

The area of this research was chosen in the surroundings of the village Strríbrné Hory in the Bohemian-Moravian Uplands (Fig. 1). This area is situated in the $\mathrm{W}$ of the town Prribyslav in the centre of the Czech Republic. It consists of the Sázava River

Corresponding author: Jan Juráček, MSc., research fields: tectonics, geomorphology, Cretaceous paleogeography and paleontology. E-mail: j.juracek@ muzeumhk.cz. zone with the right-side tributary system of the Borovský potok Brook. The lowest part is taken by river flat of the Sázava River at an altitude of 430-440 $\mathrm{m}$ whereas the highest part is the Stríbro Hill $(509 \mathrm{~m})$ and planation surface (etchplain) on a watershed at 510-520 m.

The researched area is predominantly formed by variously migmatized sillimanite-biotite paragneisses [6]. Sedimentary formations are very rare. They are formed by Lower Permian non-metamorphic conglomerates researched [9] and Quaternary fluvial or deluvial deposits.

The most prominent structure phenomenon of the region is deep-seated fault near Pribyslav of the $\mathrm{N}-\mathrm{S}$ direction and crossing faults of the NW-SE, ENE-WSW and NE-SW orientations [7]. This Prribyslav-Vitice fault zone represents NNE-SSW sinistral strike-slip fault marked by a zone of mylonitization [8]. It represents very important seismic zone [3] and geophysical boundary [5]. 


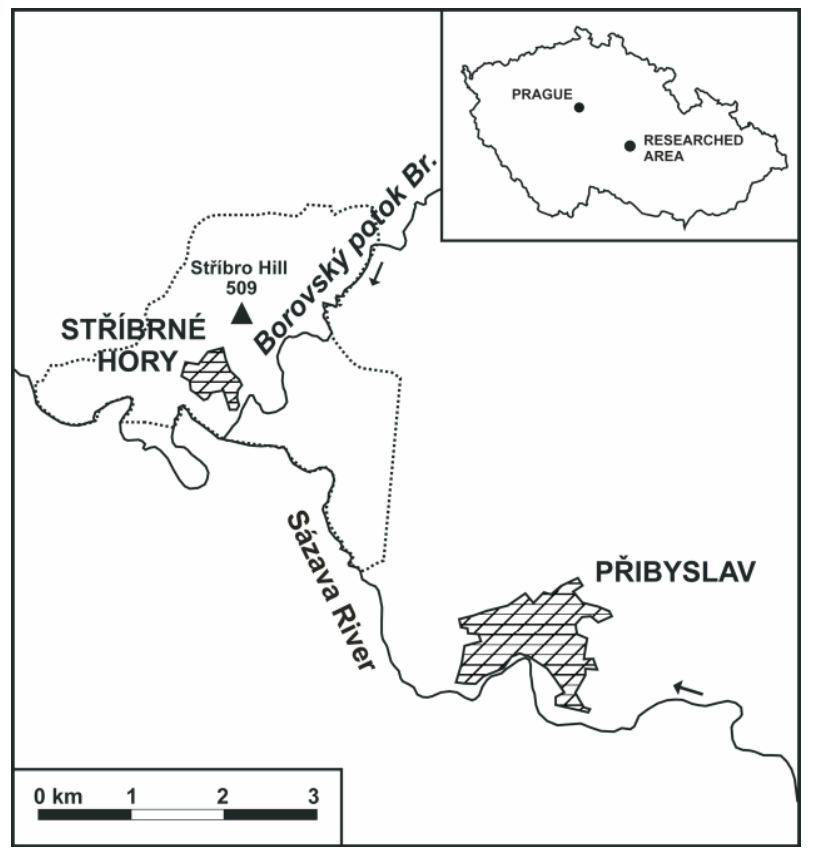

Fig. 1 Location of the researched area.

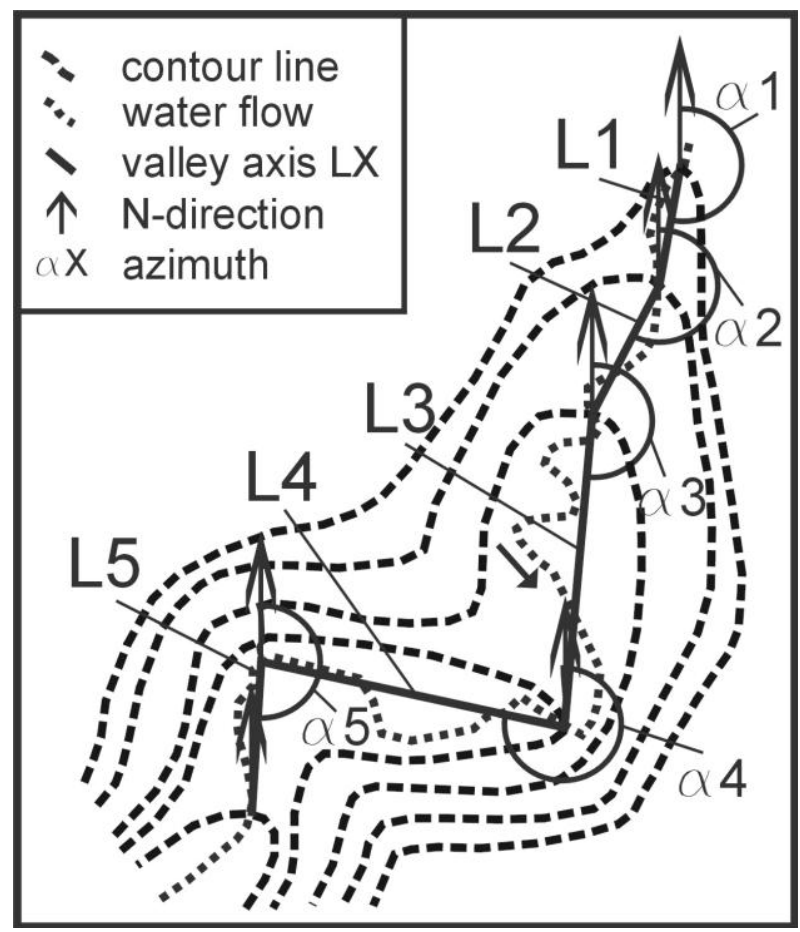

Fig. 2 Determination of the azimuth and the length of valley axes in general.

\section{Methods}

The database of the dip azimuth and the dips of foliations and joints were taken from the report of detailed geological mapping [4] which was carried out on a scale of 1:10,000. The data were consisted of 321 foliations and 643 joints from 35 documentary sites in the area of about $6.5 \mathrm{~km}^{2}$. The data were evaluated in the program Spheristat. The diagrams were constructed in an equal area (Schmidt net) on the lower hemisphere using axial data type.

The valley axes were constructed on a topographic map on a scale of 1:25,000 with contour line interval 5 $\mathrm{m}$, using the Corel Draw SW. They were drawn by connecting lines between intersection points of contour lines (Fig. 2). They were also constructed by a usage of break points of valleys in case of absence of contour lines in the bends of valleys.

The next step was a calculation of their azimuth (Fig. 2) and the lengths of valley segments in the program Autocad. They were processed 712 valley axes in a total. A scheme of valley segments is shown in the Fig. 3.

Valley axes according to their lengths were plotted to compare with frequency of the orientations of the foliations and the joints by a usage of the rose diagrams in the program excel. The similar trends were visually investigated on the basis of correspondence of the peaks in the charts. The data were sorted into decimal statistical intervals.

\section{Results}

The foliations were concentrated mainly in the

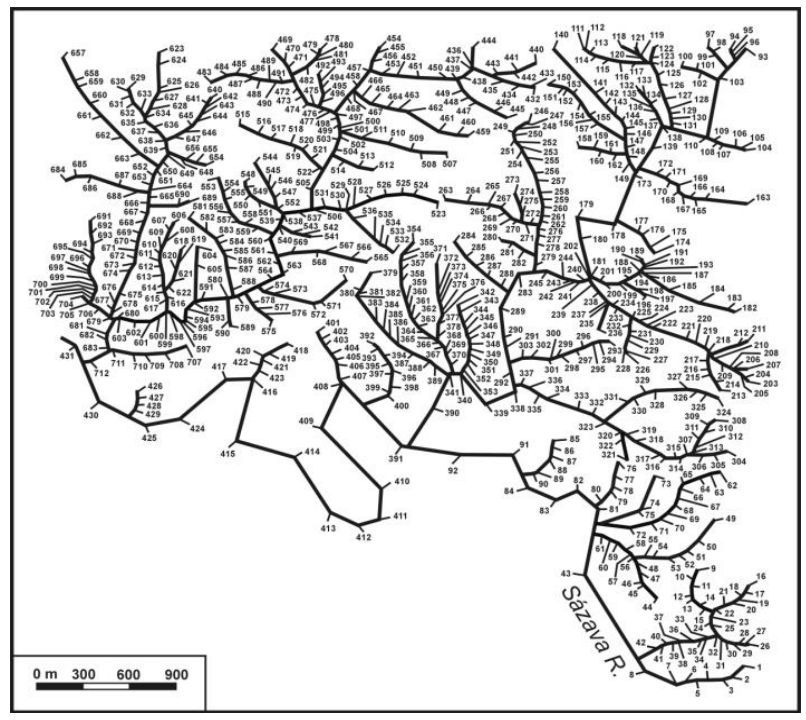

Fig. 3 System of valley axes in the researched area. 
strike from NNE-SSW to NE-SW with the dip $75^{\circ}$ to ESE-SE (Fig. 4). The diagram of the joints (Fig. 5) shows three maxima. The joints near the centre were in the strike NW-SE dipped $25^{\circ}$ to $\mathrm{SE}$, the second group of the joints downward the diagram with the strike WSW-ENE and the dip $75^{\circ}$ to NNW and the smallest maximum on the right side of the diagram is directed from the strike NNE to SSW and with the dip $70^{\circ}$ to WNW.

A distribution of the dip azimuth of the foliations (Fig. 6) shows predominantly direction to the ESE, ENE, NW-SE, NE and N. They coincide with the azimuth of valley axes (Fig. 9) only in the trend of SE but they usually show opposite positions. The frequency of the dip azimuth of joints (Fig. 7) is mostly distributed to the W, NNW, NW-SE, WNW-ESE and N-S. They correspond with the azimuth of valley axes (Fig. 9) in the W, SE and WNW.

An arrangement of the dip azimuth of steep joints

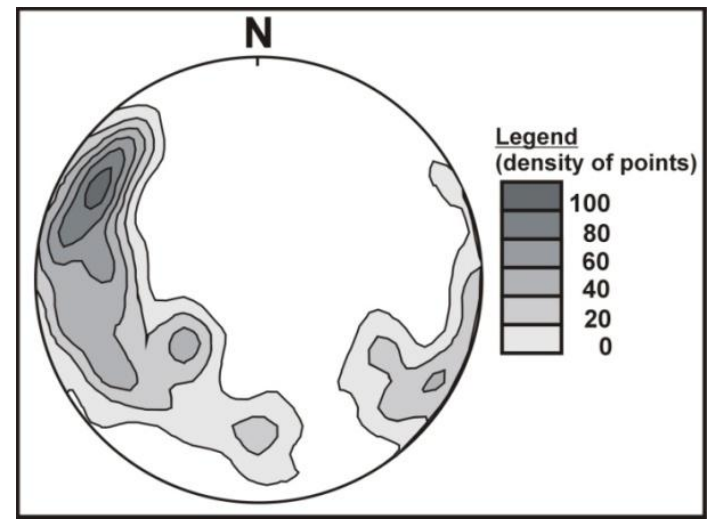

Fig. 4 The density of the poles of foliations.

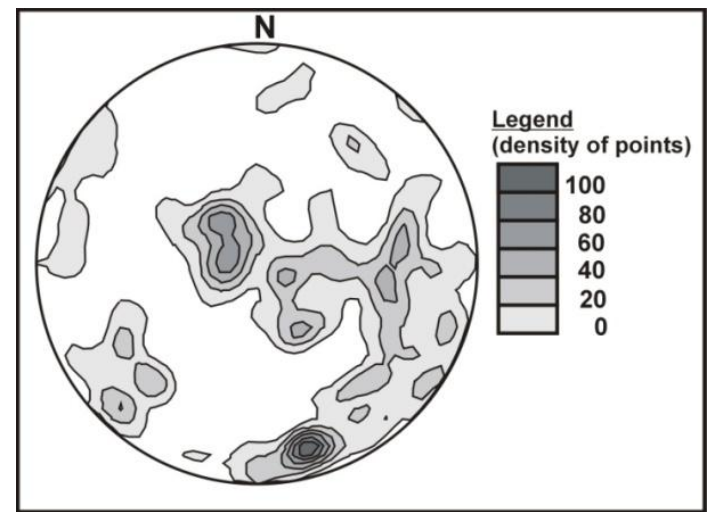

Fig. 5 The density of the poles of joints.

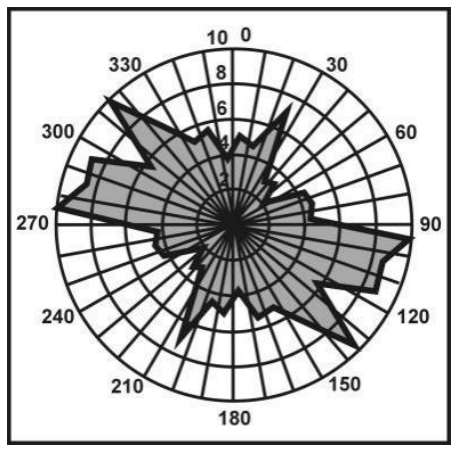

Fig. 6 Frequency of the dip azimuth of foliations.

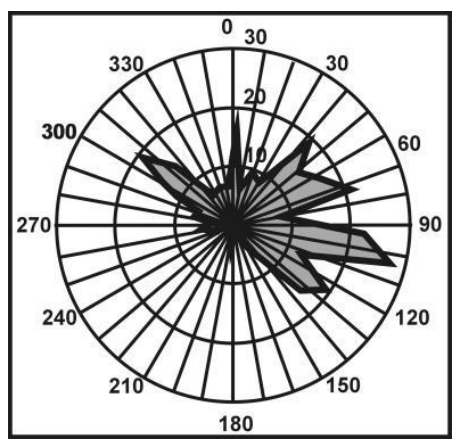

Fig. 7 Frequency of the dip azimuth of joints.

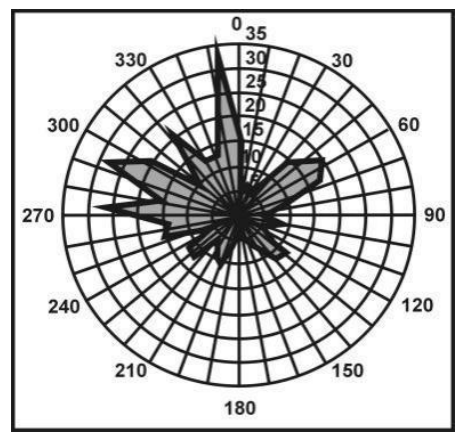

Fig. 8 Frequency of the dip azimuth of steep joints.

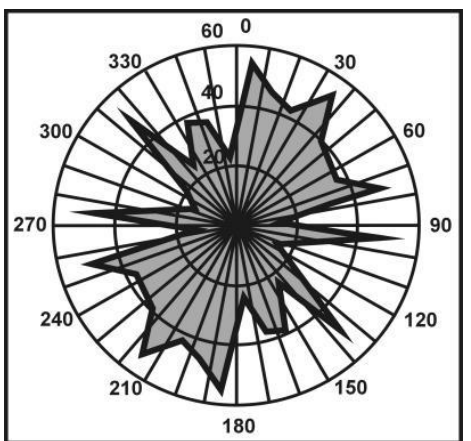

Fig. 9 Frequency of the azimuth of valley axes.

with the dip $>45^{\circ}$ (Fig. 8) forms mainly N-trend, less to the ENE, WNW and W. They demonstrate conformity with the azimuth of valley axes (Fig. 9) in the direction to the W and WSW. 
A distribution of the strike of foliations (Fig. 10) is the most considerable in the NE-SW, NNE-SSW, NNW-SSE and W-E. They are complementary with the direction of the valleys (Fig. 13) in the NNE-SSW and W-E. The strikes of joints (Fig. 11) are especially

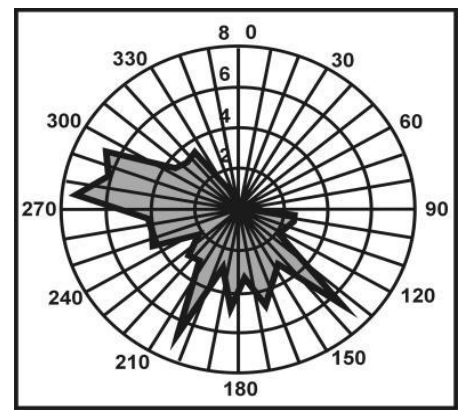

Fig. 10 Frequencies of the strike of foliations.

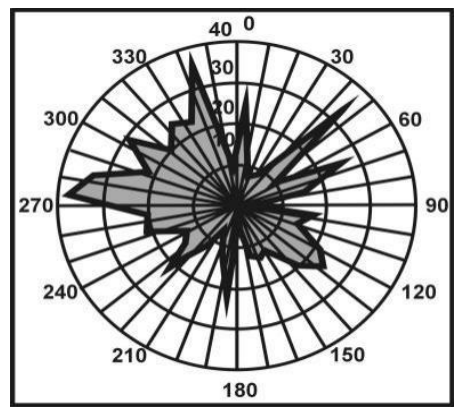

Fig. 11 Frequencies of the strike of joints.

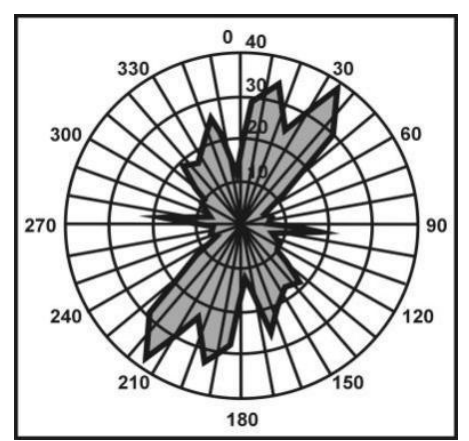

Fig. 12 Frequency of the strike of steep joints.

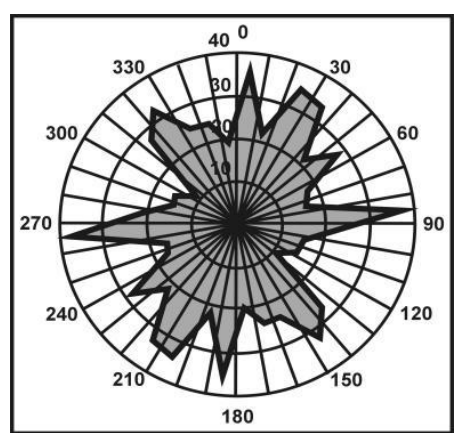

Fig. 13 Frequency of the direction of valley axes.
N-S, NE-SW, ENE-WSW, W-E and NW-SE. They represent a comparison with the direction of valley axes (Fig. 13) in W-E and NW-SE.

The strikes of steep joints (Fig. 12) have the most important directions N-S, NNE-SSW, E-W and NW-SE. They show a concordance with the direction of valley axes (Fig. 13) in W-E, NW-SE and NNE-SSW.

\section{Discussion}

Overall mirror-like symetric distribution of the azimuth of valley axes in contrast to the dip azimuth of foliations can mean that the streams flow against the dips of foliations generally but except the SE when they track the dip.

The azimuth of valley axes is identical with the azimuth as joints as steep joints to the $\mathrm{W}$, WNW and SE. It is not sure a determination of the SE-dip due to the azimuth of valley axes in that it can be influenced either by the dip azimuth of foliations or joints. The azimuths of joints are directed to the W and WNW. Steep joints have significance in the trend to the WNW.

The directions of valley axes coincide with the strike of foliations in the NNE-SSW and W-E and also with the strike as joints as steep joints in the strike W-E, NW-SE and NNE-SSW. Valley axes can be predisposed by the strike of foliations as joints. The trend NW-SE is primarily influenced by the strike of joints. The peaks of steep joints in opposite to all joints show significance of the steepness on valley progress.

\section{Conclusion}

Prevailing directions of valley axes are concentrated in the direction of NW-SE, W-E and NNE-SSW. The trends of geological structures are in a coincidence with the direction of valley axes in the NNE-SSW, SE, E-W, NW and WNW. The directions of valleys coincide with the system of the foliations and steep joints. 


\section{References}

[1] Fryirs, B., and Fryirs, K. A. 2005. Geomorphology and River Management: Applications of the Style Framework. Malden: Blackwell Publishing.

[2] Juracek, J. 2014 "The Evaluation of Geological Structures by the Vector Analysis of Valley Axes." Zeitschrift für Geomorphologie 58 (2): 201-15.

[3] Lenhardt, W. A., Švancara, J., Melichar, P., Pazdírková, J., Havír, J., and Sýkorová, Z. 2007 "Seismic Activity of the Alpine-Carpathian-Bohemian Massif Region with Regard to Geological and Potential Filed Data." Geologica Carpathica 58 (4): 397-412.

[4] Lukášová, R. 1961. Report of Geological Mapping in 1960. In Pokorný, J. 1964: Final Report on Prospection of $\mathrm{Pb}-\mathrm{Zn}$ Deposits in the Area of Havlíčkův Brod. Manusript report. Prague: Czech Geological Survey. [in Czech]

[5] Novotný, M. 2012 "Depth-Recursive Tomography of the
Bohemian Massif at the CEL09 Transect-Part B: Interpretation." Survey of Geophysics 33 (2): 243-73.

[6] Stárková, I., and Skácelová, D. 1998: Geological Map of the Czech Republic 1:50,000, No. 23-22 Žd'ár nad Sázavou. Prague: Czech Geological Survey. [in Czech]

[7] Štěpánek, P., Břízová, E., Fürych, V., Hanžl, P., Kadlecová R., Kirchner, K., Lhotský, P., Lysenko, V., Pertoldová, J., Roštínský, P., Skácelová, D., Skácelová, Z., Verner, K., and Vít, J. 2008. Geological Map of the Czech Republic 1:25,000 with Explanatory text, No. 23-222 Přibyslav. Prague: Czech Geological Survey. [in Czech]

[8] Urban, M., and Synek, J. 1995. "Moldanubian Zone. Structure." In Pre-Permian Geology of Central and Eastern Europe, edited by Dallmeyer, R. D., Franke, W., and Weber, K. Berlin-Heidelberg-New York: Springer.

[9] Vomelová, H. 1998 "Nemetamorfované slepence u Stříbrných Hor.” MSC thesis, Masaryk University. 